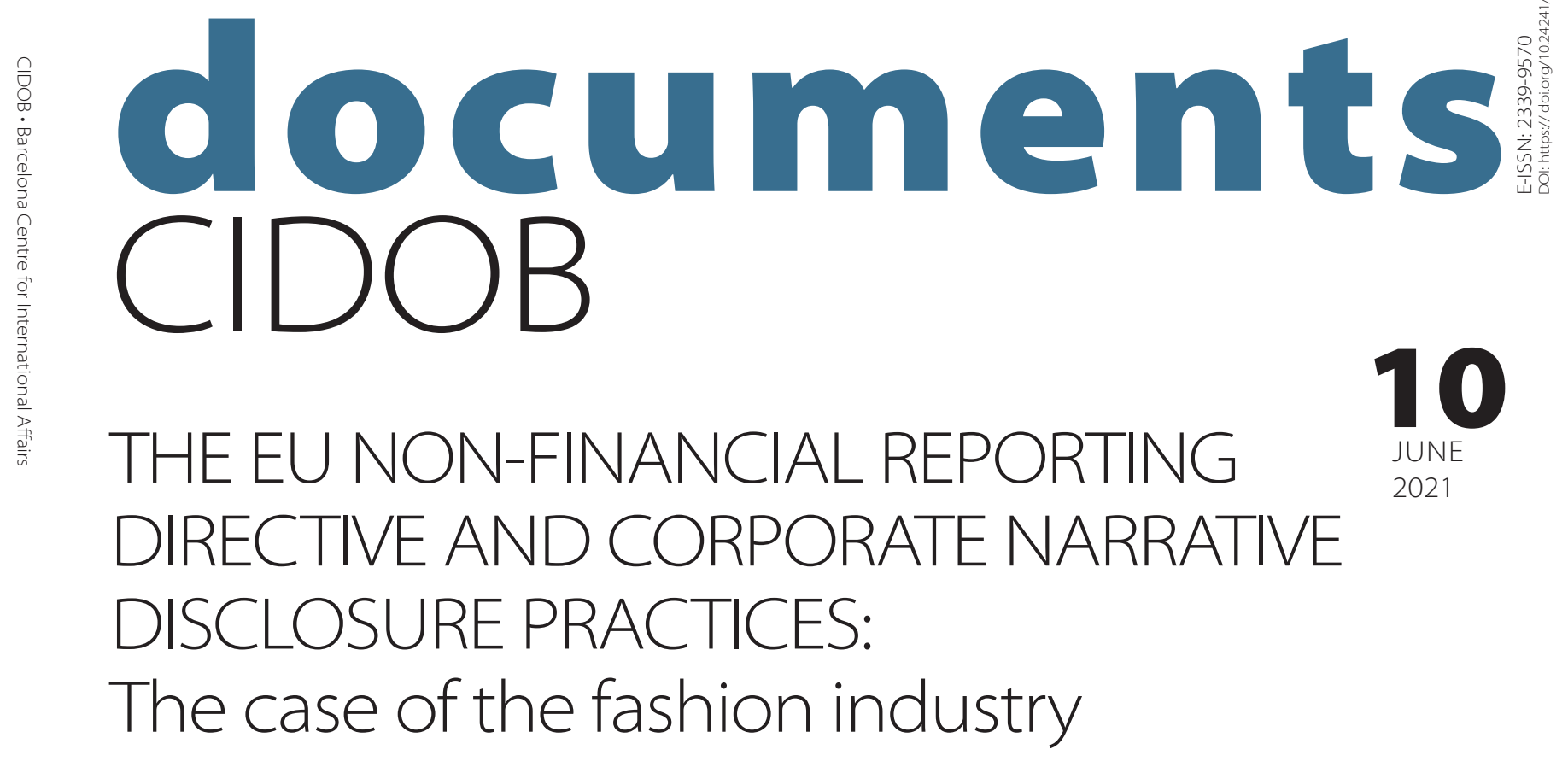

Lela Mélon, Executive Director of the Planetary Wellbeing Institutional Framework, Pompeu Fabra University.
Associate Professor of Sustainability in Business Law, ESCl-UPF.
Lela.melon@upf.edu
ORCID: https://orcid.org/0000-0002-9018-4135

Winner of the 21st Century Europe Talent Award, launched by CIDOB and Banco Sabadell Foundation in collaboration with Fundació Catalunya Europa, in the framework of Programa Talent Global.
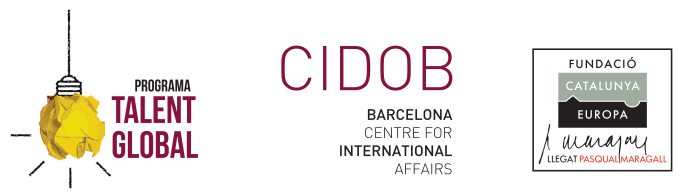

\title{
BSabadell Fundació
}

\section{Introduction}

The shift in the narrative of corporate social responsibility (CSR) to one of sustainability has not been adequately reflected in business conduct. In reality, weak sustainability practices that produce similar results to CSR practices have often continued, and there has been a failure to incorporate strongly more sustainable practices that would cause an organic business change that is reflected in all corporate operations and departments and minimise negative environmental and social impacts. In the EU, the most relevant mandatory regulation for distinguishing between weakly and strongly sustainable corporate practices regulates corporate reporting of entities with the potential to significantly impact the sustainability of the market as a whole. Sustainability often requires qualitative assessment, as it can prove difficult to determine quantitatively: narrative reports are crucial for understanding corporate sustainability practices and their comparability, especially within a particular sector. To that effect, the EU Non-Financial Report-
Abstract: The present work tackles the crucial issue of global sustainability and the challenge of policy coherence around sustainability, focusing on sustainability reporting in the fashion industry in the EU. As the legislative framework has grown increasingly rigorous, so has the importance of well-formed and carefully focused legislation. By examining non-financial (sustainability) reporting in the fashion industry and its challenges, this paper exposes the most plausible next steps to be taken in terms of requirements for non-financial reporting as well as changes to corporate purpose and behaviour. This paper their analysis in relation to sustainability science, providing an interdisciplinary and transdisciplinary understanding of the sustainability reporting and adjacent framework in the EU.

Key words sustainability reporting, environmental footprint, sustainable business practices, fashion industry, EU policies engages with policy and legal considerations, practical behaviour and

ing Directive (NFRD) and the suggested amendments made narrative sustainability reporting compulsory for large corporate legal entities in the EU, including in sectors that are not particularly amendable to sustainability disclosure.

This work focuses on the world's second-most unsustainable industry - fashion and analyses reporting practices and their objective transparency, while allowing for a qualitative assessment of their impact on sustainability. Reaching beyond the "one-size-fits-all" approach, the present work differentiates between so-called "fast fashion" companies, luxury 
brands and sustainable (ethical) fashion. It compares their reporting practices in general and, more specifically, those under the NFRD, in order to critically appraise their approaches to reporting the relevant sustainability data. Relevant and truthful reporting is of crucial importance for informing the market in terms of benchmarking sustainable practices and providing relevant information to consumers. Hence, the analysis of existing practices is indispensable for future policymaking, especially in the light of disruption caused by the COVID-19 pandemic, which provides an unprecedented opportunity for industries to move away from "business as usual". Widespread greenwashing in the fashion industry calls for novel solutions in terms of policymaking and disincentivising the further use of such practices. The insight into the proposed amendments to the NFDR provided by the findings of this paper on the fashion industry can serve
Whether we consider fast fashion or haute couture, the business of fashion is not environmentally nor socially sustainable. other issues. The impact of COVID19 on the luxury fashion industry has been especially adverse. With China accounting for $90 \%$ of global luxury market growth in 2019, the country's lockdown severely disrupted the demand side of luxury fashion (Bain and Company, 2020). Almost immediately after, when the virus soared throughout Italy and a national lockdown was imposed there, the supply side suffered severe disruption as many luxury fashion brands are headquartered and have key suppliers in Italy. Sustainable fashion, on the other hand, is an alternative trend that works against unsustainable fashion practices, "encompassing a variety of terms such as organic, green, fair trade, sustainable, slow, eco and so forth, each attempting to highlight or correct a variety of perceived wrongs in the fashion industry" (Cervellon et al., 2010) in terms of their negative environmental and social as a basis for further research and the amelioration of existing EU policy in the field. Rather than focusing on the purely academic context, the analysis of existing practices gives an important signal for the policy amendments necessary in the field, following the sustainability science requirement of a multifaceted approach that encompasses practical aspects while supporting academic findings and policy advances.

\section{The (un)sustainability of the fashion industry}

\subsection{The state of the art}

The fashion industry is heterogeneous in nature. Encompassing "fast fashion", luxury fashion and sustainable fashion (Pedersen and Andersen, 2015), it has gained a reputation for being unsustainable (Arriga, 2015). "Fast fashion" is the name given to low-cost clothing collections that mimic current luxury fashion trends. Its definition in the Cambridge Dictionary (2021) shows its inherently unsustainable nature: "clothes that are made and sold cheaply, so that people can buy new things often". While it thrived pre-COVID-19, the industry is currently struggling: by way of example, the Swedish multinational H\&M reported a fall of $90.7 \%$ of net benefits in the year 2020, prompting it to close 350 shops globally (H\&M Group, 2020). Similarly, the UNCTAD (2020) reported a fall in consumer spending on fashion and accessories by $43 \%$ in 2020. But the business model of buy-use-dispose and offering several collections per year found another outlet, online sales. Although this could not make up for decreased in-store sales (The Business Research Company, 2020c), it nonetheless allowed the H\&M brand to continue existing. Luxury fashion, on the other hand, consists of goods that are not necessary for daily life, but which are sold at elevated prices due to the high quality of the products (Fionda-Douglas and Moore, 2009). While they are not based on mass production and consumption, they bring their own sustainability-related concerns: the destruction of inventory to preserve the value of the brand, human rights violations across their supply chains (Shen et al., 2020) and the use of fur (Ferreira, 2016), amongst impact. The design, manufacturing and use philosophy it has formed and the trend towards maintainability seeks to create a system which is sustainable indefinitely (Pencarelli et al., 2020). In terms of the disruption caused by the COVID-19 pandemic, sustainable fashion performed better than fast fashion and luxury fashion, experiencing year-on-year decline of $3.24 \%$ in 2020 (The Business Research Company, 2020b), as compared to $12.32 \%$ for fast fashion (The Business Research Company, 2020c) and around 35\% in luxury fashion (McKinsey \& Company, 2020). This attests to the fact that social and environmental sustainability ultimately also results in economic sustainability and stability.

Beyond COVID-19's disruptive impact, the industry had already received a strong demand-side signal that consumers' focus was shifting away from fast fashion, as shown by several fast fashion company bankruptcies. ${ }^{1}$ While this is a welcome development, Generation Z currently has a limited impact on the industry's behaviour given their low purchasing power, meaning additional changes are needed to push the industry towards more sustainable practices. In order for public pressure (e.g. through financial market pressure, reputational pressure and a changed attitude of consumers with significant purchasing power) to be exerted on corporations in the fashion industry, heightened awareness about sustainability challenges needs to be coupled with relevant, comparable, transparent and material corporate reporting on sustainability issues in the industry.

\subsection{The fashion industry's sustainability footprint: where's the catch?}

Globalisation brought consumers endless possibilities in terms of available goods. As regards fashion garments, their low price and regularly changing collections prompted consumers to engage in overconsumption (Bick et al., 2018), causing a $400 \%$ increase in consumption in the last decade and a signifi-

1. For example, Forever 21 and Neiman Brothers: see Reuters (2019) and CNBC (2020). 
Figure 1. Global Material Flows for Clothing in 2015

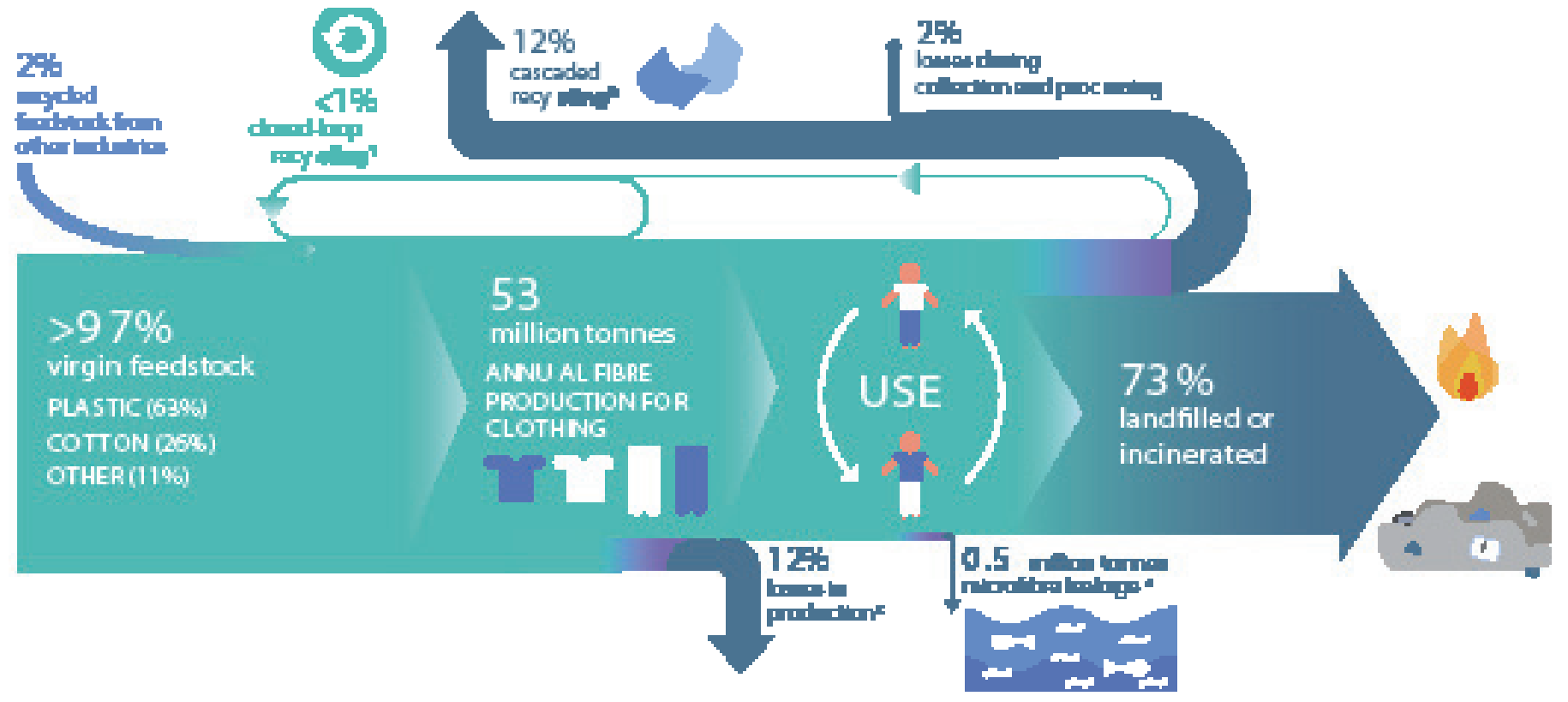

1. Recycling of clothing into the same or similar quality applications

2. Recycling of clothing into other, lower-value applications such as insulation material, wiping cloths, or mattress stuffing

3. Includes factory offcuts and overstock liquidation

4. Plastic microfibres shed through the washing of all textiles released into the ocean

Source: Ellen MacArthur Foundation (2017:20).

cant amount of waste. ${ }^{2}$ In the last decade, the awareness of the damage caused by the overproduction and overconsumption of fashion garments has risen, increasing the understanding of the hidden costs of cheap clothes: the carbon footprint of the global supply chain (Ellen MacArthur Foundation, 2017); human rights violations throughout the supply chain (German Institute for Human Rights, 2018); water usage and water pollution (Khan and Malik, 2014); and the creation of waste (Jacometti, 2019). While these sustainability challenges have been known about for a long time, the fashion companies have not been systematically addressing them - or reporting on them.

How should we determine what is material in terms of sustainability for the industry as a whole? The scholarly work on the life cycle impact assessment of supply chains in the fashion industry (Bick et al., 2018) and the work of non-governmental organisations on the environmental and social footprint of the fashion industry (Ellen MacArthur Foundation, 2020) provide a strong basis for deciding the core information fashion companies should disclose - and it is not the proportion of recycled materials they use for their packaging.

The UNEP's 2020 report on sustainability and circularity in the fashion industry states that the fashion industry's sustainability hotspots are well established and agreed upon (UNEP, 2020: 9). It may thus be argued that these are the material issues for disclosure in corporate non-financial annual reports. The most pertinent sustainability hotspots identified in the fashion industry are: ${ }^{3}$ excessive water use, land use change and deforestation, loss of biodiversity, water pollution, the use of pesticides and fertilisers, $\mathrm{CO}_{2}$ emissions, forced labour, substandard working conditions, below minimum wage, below living wage, child labour, occupational health and safety impacts, gender-related discrimination and violence, excessive working hours, migrant workers (refugees), restrictions on forming or joining a trade union, restrictions on collective bargaining and corruption. In the case of luxury fashion, additional sustainability hotspots (also carrying ethical concerns) noted relate to the materials used (the use of fur, leather and silk as resources) (Karaosman, 2018) and to the non-intense use of the clothing in question. Hence, as a minimum, the material non-financial information that the companies in the fashion industry disclose should include these key sustainability hotspots. But does it? The following section explores the history and critically appraises the development of the NFRD, arguing that there is room for improvement and that such an improvement should necessarily follow the defined sustainability hotspots for the company in question.

\section{The development of the Non-Financial Reporting Directive and its applications}

\subsection{The history and aim of the directive}

Since 2018, the NFRD has meant that large companies are obliged by EU law to disclose certain information on the way they operate and manage social and environmental challeng-

2. By way of example, it has been found that $85 \%$ of garments disposed of end up in landfill, while the average life of a piece of garment has fallen to 5.4 years. See: Environmental Protection Agency (2014).

3. The scholarship often determines them in terms of production stages, e.g. the raw

materials phase, fabric production phase, manufacturing phase, retails phase, phase of consumer use, the end of life phase and the transport across the entire supply chain. See e.g. SMART (2017). 
es, in an attempt to aid investors, policymakers and other stakeholders to evaluate the non-financial performance of large companies. The directive applies to large public-interest companies with more than 500 employees, which means approximately 6,000 entities - including European fashion companies - are required to engage in non-financial reporting (if they are listed or designated by national authorities as public-interest entities). The directive has been accompanied by two sets of non-binding guidelines: one to ensure corporations report relevant, useful and comparable information and the other to aid companies to report climate-related information and to integrate the recommendations of the Task Force on Climate-related Financial Disclosures (TCFD).

The NFRD requires large companies to publish reports on their policies regarding environmental protection, social responsibility and treatment of employees, respect for human rights, anti-corruption and bribery, and diversity on company boards (age, gender, educational and professional background). There is flexibility around the format, with companies choosing whichever they consider most useful, using international, European or national guidelines (e.g. the UN Global Compact, the OECD guidelines for multinational enterprises, ISO 26000, etc.), while also considering the EU NFRD guidelines. While the NFRD's provisions are not very detailed as to the matters to be disclosed, the recitals of the directive are very vocal on the content of the information expected from the companies: "at least environmental matters, social and employee-related matters, respect for human rights, anti-corruption and bribery matters" and "a description of the policies, outcomes and risks related to those matters" (NFRD, Recital 6), including "due diligence
An open non-financial reporting regulation brought about a cherry-picking approach, where companies report about their positive achievements and omit their sustainability hotspots that are truly relevant. somewhat surprising that the non-financial reporting in the EU did not produce relevant information on the sustainability of European businesses beyond what already existed in the market. Coupled with the fact that the NFRD calls upon member states (MS) to ensure enforceability of the directive's rules and the existence of scientific findings on sustainability hotspots across industries, the modest outcome of the implementation of the NFRD is surprising.

Despite clearly being focused on obtaining relevant information on corporate environmental and social impact, the directive has achieved moderate results, with its revision called for in the framework of the recent EU Green Deal. While the non-financial information to be included has from the beginning been "information to the extent necessary for an understanding of the undertaking's development, performance, position and impact of its activity, relating to, as a minimum, environmental, social and employee matters, respect for human rights, anti-corruption and bribery matters[...]" (NFRD, Article 1.1), the non-financial reports have been reporting on the positive environmental and social corporate impact, while refraining from disclosing the information regarding the negative impacts and the planned corporate actions to mitigate those impacts. As The Alliance for Corporate Transparency project noted in its 2018 Research Report, the lack of specification in sufficient detail about what information and key performance indicators should be disclosed led to the situation of a majority of companies acknowledging the importance of environmental and social corporate issues yet not providing clear information in terms of concrete issues, targets and principal risks, which in turn prevents stakeholders from understanding the company's processes implemented by the undertaking" and, where relevant and appropriate, "its supply and subcontracting chains" (NFRD, Recital 6). Furthermore, in terms of environmental matters it calls for "details of the current and foreseeable impacts of the undertaking's operations on the environment, and, as appropriate, on health and safety, the use of renewable and/or non-renewable energy, greenhouse gas emissions, water use and air pollution" (NFRD, Recital 7). Likewise, in the field of social and employee-related matters, it calls for "actions taken to ensure gender equality, implementation of fundamental conventions of the International Labour Organisation, working conditions, social dialogue, respect for the right of workers to be informed and consulted, respect for trade union rights, health and safety at work and the dialogue with local communities, and/or the actions taken to ensure the protection and the development of those communities" (NFRD, Recital 7). That information is considered adequate for the most pertinent corporate sustainability issues and should account for their severity in terms of scale and gravity, whether they stem from the corporation's own activities or are just linked to its operations, products, services and business relationships (including its supply and subcontracting chains). The administrative burdens this could bring to small and medium-sized undertakings are noted. The recitals therefore bring a lot of clarity about the exact aim of the directive, making it impact, development, performance and position, as required by the NFRD. Furthermore, in order for the non-financial information disclosed by individual companies to inform on the sustainability of their business, it must also be material, comprehensive and comparable, which is now to be achieved with the revision of the NFRD. By way of example, while corporations disclose some information on the most important environmental issues - such as water use, pollution and waste - they are not considered across the supply chain and corporate operations. Neither are corporations reporting on concrete impacts and their management of those sustainability challenges. Regarding social issues, reports contain information on the number of direct employees, overall gender balance, anti-discrimination policies and health and safety, setting aside outsourced workers and region-sensitive issues. This provides very limited insight into corporate social sustainability, as a substantial portion of corporate operations is outsourced, meaning the sustainability of corporate conduct depends on the sustainability of the practices of suppliers. In fact, transparency on supply chains and audits has been limited. Where companies do report on human rights issues, they express their commitment to human rights protection without giving an account of their human rights due diligence or a clear statement of pertinent challenges and their 
effective management. Directly contrary to the aim of the NFRD, the reports provide a generalised account of sustainability challenges without applying them to the practices of the company in question.

The NFRD applies a "comply or explain" principle - requiring the company to disclose material information on sustainability-related matters or explain why such a disclosure has not been made. But this does not mean that companies should or will engage in a general non-disclosure, as companies may draw negative publicity that increases their business risks and damages their reputation in the market. It has been shown that, if formulated appropriately, complying with or explaining principles are effective ways to improve corporate behaviour and enhance corporate transparency (Harper Ho, 2017). The lack of clarity on the notion of materiality in the NFRD has also spilled over into national legislation (Jeffwitz and Gregor, 2017) and arguably hampered the quality of non-financial reporting in the European Union. Beyond determining that the NFRD's materiality is a double materiality (environmental and social materiality that may be financially material), the suggestions of what is to be deemed material do not amount to a firm definition of what is material. For example, while allowing flexibility by calling on corporations to determine the key sustainability-related issues, the guidelines simply re-state the wording of the NFDR and add in the "fair view of the information needed by relevant stakeholders" from the Accounting Directive - albeit calling for consideration to be given to actual situations and sectoral specificities. The Accounting Directive calls for similar information to be deemed material across a specific industry to allow for direct comparison of relevant non-financial disclosures by companies in the same sector. As such, the NFDR and the accompanying guidelines should narrow down the scope of corporate discretion as to what is material in a particular sector. This is currently not the case. What is material remains at the discretion of the company in question, watering down the requirements not to mislead about material information or disclose immaterial information and to clearly distinguish facts from views or interpretations. Furthermore, the NFRD and the accompanying guidelines disregard the possibility not only of underreporting but also of large corporate entities rolling over their sustainability-related commitments and obligations to their suppliers, which are oftentimes small and medium-sized companies. Such behaviour risks sabotaging the aim of the directive not to increase (administrative) burdens for those companies. While the NFRD represents a major first step in the right direction by highlighting the importance of non-financial information disclosure, the NFRD's implementation in practice shows that there is room for improvement.

\subsection{The Impact Assessment: how to approach the revision of the Non-Financial Reporting Directive}

In early 2020, the EU Commission issued its Inception Impact Assessment on the revision of the NFRD, allowing citizens and stakeholders to provide feedback on the intended activities. Given the shortcomings of the initial NFRD, the Commission envisaged major enhancements to the exist- ing legal framework as "[t]he demand for better information from investee companies is driven partly by investors needing to better understand financial risks resulting from the sustainability crises we face" and "the NFRD does not adequately respond to these needs" (European Commission Impact Assessment, p. 1). The Commission defined two general groups of issues to be tackled by the NFRD revision: a) the lack of adequate publicly available information on how non-financial and sustainability issues impact companies as well as how companies impact society and the environment; b) the incurrence of unnecessary, avoidable costs related to the reporting of non-financial information, also by virtue of different disclosure requirements contained in other EU legislation and the pressure exerted on companies by sustainability rating agencies, data providers and civil society. ${ }^{5}$ The main objectives of the revision, according to the EU Commission, are threefold: 1) ensuring investor access to adequate corporate non-financial information to allow for accounting for sustainability-related risks, opportunities and impacts in their investment decisions; 2) ensuring that the stakeholders have access to adequate corporate non-financial information to hold the companies accountable for their unsustainability; and 3) reducing unnecessary burdens related to non-financial reporting. All in all, the EU Commission is aiming to ensure that after the revision, the NFRD provides the information to allow unsustainable environmental and social impacts to be understood.

As to the policy options, the Commission laid out the following: 1) continuing with the non-binding guidelines, but revising the already existing guidelines and issuing new guidelines on new topics; 2) exploring the use of standards, endorsing the existing ones or creating new ones; 3) revising and strengthening the provisions of the NFRD by providing more specific detail on the content of non-financial information, requiring the use of a non-financial reporting standard, modifying the scope of the directive, strengthening the provisions regarding the assurance of non-financial information, clarifying and harmonising provisions on where non-financial information should be provided, and strengthening the enforcement regime.

While the first option (revising and issuing guidelines) does not seem to be the most optimal, given the experience with the 2017 and 2019 EU guidelines, the second and third options might provide a better way forward. However, the use of standards on sustainable corporate conduct has also proved to be of limited effectiveness, and they function in a similar manner to the guidelines (Vigneau et al., 2015). As such, the third option seems to be the most optimal, as it allows for a holistic reform of the reporting system, approach-

4. Especially regarding comparability or reliability of non-financial information; reporting non-financial information that users think is necessary and relevant; lack of reporting in general; and the availability of the created reports.

5. Inadequate reporting means investors cannot account for the actual social and environmental impacts of their investments, causing systemic risks to the economy due to investments not adequately pricing in sustainability-related risks, which causes inadequate capital flows to sustainable companies. This also creates an accountability deficit, as civil society organisations, trade unions and so on cannot effectively hold companies accountable for their impacts on society and the environment, while delivering EU Green Deal is hindered by the regulatory and market failures. 
ing the matter of non-financial reporting from a new perspective. While this might impose additional administrative burdens on companies, in the light of climate emergency as well as the accelerated transformation of sustainability-related risk into financial risks, those burdens are awaiting the companies even in the absence of such a revision of the NFRD. The changing business and environmental reality means that companies need to be aware of their sustainability hotspots in order to be able to include the risks of climate change and other sustainability-related issues in their risk assessment and risk mitigation plan(s). The simplification of operations across the single market is expected to be a positive spill-over effect, helping prevent diverging non-financial reporting requirements at national level and contributing to the longterm resilience of the economy.

Some reservations were expressed about the global competitiveness of EU companies due to these additional costs to which non-EU companies are not currently subject, but calls for sustainability-related disclosure are being made around the world. This situation could be further remedied by extending the scope of the NFRD to entities operating in the EU but based elsewhere. ${ }^{6}$ A major revision of the NFRD is also expected to have a significant, indirect positive impact on social issues, such as labour standards, non-discrimination and social inclusion through greater capital flows to companies addressing social issues and with good social performance and through the change in the way companies manage related risks in their supply chains.

\subsection{Calls for reform}

The Inception Impact Assessment drew 78 responses from public and private entities. The majority called for a substantial revision of the NFRD, the limiting of members states' discretion on the implementation of the directive and strengthening and better defining the corporate reporting obligations, while also imposing those obligations on non-EU entities doing business in the EU.

The responses called for a substantial revision of the NFDR content, essentially introducing a new system of non-financial reporting in the EU. This renewed reporting was envisaged by stakeholders as one that represents maximum harmonisation and/or establishes a Level 1 Regulation in accordance with the Article 114 of the TFEU to prevent diverging national requirements. ${ }^{7}$

6. One of the options in the EU Commission public consultation on the NFRD revision ("Expand the scope to include large companies established in the EU but listed outside the EU"). See: Asociación Española de Directivos de Responsabilidad Social.

7. See: e.g. Autorité des marchés financiers (AMF) Feedback on Non-financial reporting by large companies; Danish response to the Roadmap for the revision of the Non Financial Reporting Directive (NFRD); Client Earth's response to the roadmap consultation for the inception impact assessment of the revision of the NonFinancial Reporting Directive; r3.0 Feedback on Non-financial reporting by large companies; Rethink Plastic Alliance's response to the roadmap consultation for the inception impact assessment of the revision of the Non-Financial Reporting Directive; CDSB response to Inception Impact Assessment on the Revision of the Non-Financial Reporting Directive; Impact Investing Institute's Response to the Non-financial Disclosure Regulation (NFDR) Inception Impact Assessment; ETUC Position for a European directive on mandatory Human Rights due diligence and responsible business conduct (draft position).
It is interesting to note that none of the responses called for minor changes to EU non-financial reporting. According to the stakeholders that responded, the most important issue to be resolved by the revised NFRD is the issue of policy coherence: ensuring consistency with the EU's Benchmark Directive, Sustainable Finance Taxonomy and Sustainable Disclosure Regulation' but also incorporating the already developed thematic or sectoral (scientific) findings on sustainability hotspots in the reviewed non-financial reporting framework. More detailed determination of materiality by the EU Commission is called for than has been the case with the guidelines that accompanied the NFRD.

There has also been a call to strengthen enforcement mechanisms and penalties at national level in the form of a strong regulatory mechanism for penalising breaches of duties related to reporting and governance with sanctions for failures to identify, prevent or mitigate risk and impacts or to fulfil reporting requirements that are sufficiently dissuasive and proportionate and applicable to companies and their directors. ${ }^{8}$ Obviously, for the enforcement mechanisms to be strengthened, the reporting obligations need to be determined in more detail. Ideally, to avoid the generic reporting witnessed in the corporate non-financial reporting based on the NFRD, they should be linked to science-based findings and targets based on what is material in a particular industry.

As the EU Green Deal has brought significant changes to corporate regulation and corporate sustainability obligations, the proposed revision supports and accompanies the shift towards responsible business conduct in the EU. In terms of the fashion industry this means that the reporting should encompass the information on all the identified sustainability hotspots and the accompanying policies for mitigating the negative environmental and social impact of the corporations in the fashion industry. But the business models that are causing the materially adverse environmental and social impacts should also transition towards others that entail sustainable outcomes for the company and society as a whole.

\section{Non-financial reporting in the fashion industry}

\subsection{The general overview: the obligation of non-financial reporting}

Due to consumer pressure and heightened awareness of the negative impact of the fashion industry on the environment as well as society as a whole, fashion companies had already started to engage with sustainability before the NFRD came into force. Unfortunately, the same reproaches apply to the reports produced by the fashion industry as were made for the reports produced under the NFRD. According to the Fashion Revolution Fashion Transparency Index 2020 Edition, the majority of brands and retailers lack transparency

8. ClientEarth's response to the roadmap consultation for the inception impact assessment of the revision of the Non-Financial Reporting Directive; Rethink Plastic Alliance's response to the roadmap consultation for the inception impact assessment of the revision of the Non-Financial Reporting Directive and CDSB response to Inception Impact Assessment on the Revision of the Non-Financial Reporting Directive. 
on social and environmental issues, with fast fashion companies leading on transparency compared to the luxury brands. Good transparency performance in the fashion industry was also noted in the the Alliance for Corporate Transparency's (2019) report for 2018. But transparency does not automatically lead to sustainability of the business practices in question: ${ }^{9}$ not only did the index show that more than half of the participating brands scored $20 \%$ or less on environmental and social issues, the highest scoring companies on transparency (e.g. H\&M, C\&A, ASOS) have business models based on overproduction and overconsumption. The low score on environmental and social issues transparency is all the more worrisome given the index itself is built on voluntary self-reporting (only half of the brands invited agreed to participate), potentially making the results positively biased (Steiner et al., 2018).

Aside from noting the need to address unsustainable practices in the fashion industry through the revision of the NFRD, the EU acknowledged the need to revise these practices in its EU Strategy for Sustainable Textiles, guiding EU fashion companies towards "a climate-neutral, circular economy where products are designed to be more durable, reusable, repairable, recyclable and energy-efficient" by making the COVID-19 recovery of the textile industry sustainable (European Commission, 2021). The sustainable textiles initiative is based on EU recognition that textiles is a priority sector for achieving a carbon-neutral, circular economy in a range of instruments: the European Green Deal, the Circular Economy Action Plan, the Industrial Strategy, and the Commission Staff Working Document "Identifying Europe's recovery needs" accompanying the Communication "Europe's moment: Repair and Prepare for the Next Generation". The outlook of these policy documents, which is also expressed through concrete legislative proposals on sustainable corporate governance and human rights due diligence, favours a thorough transformation of unsustainable fashion practices, for which additional investment will be made available. To harvest these green investments, though, companies need to be aware of their sustainability hotspots and be transparent about them. This is essential to engaging in cooperative practices to find a timely solution in the industry as a whole. There must also be acknowledgment that fast fashion business models cannot survive in the long term: either due to the lack of resources (Ellen MacArthur Foundation, 2017) or due to the lack of demand given the growing customer awareness around sustainability (McKinsey \& Company, 2020) and the tendency for the market to require the internalisation of all negative externalities across their supply chains (UK Parliament, 2019).

9. Nearly all fashion companies included in the research depend on outsourced production located in regions with systemic human rights and natural resources abuse, particularly in terms of labour conditions and deforestation. Only $10 \%-30 \%$ of these companies report on these issues from a business-model perspective.

\subsection{Scope}

The majority of EU companies in the fashion industry escape the application of the NFRD, as they can be classified as small and medium-sized enterprises that fall short of the Article 1(1) threshold. Nevertheless, the most impactful European fashion companies are obliged to report on the non-financial aspects of their business, e.g. LVMH, Inditex, Dior, Kering, Hermès, adidas, Luxottica, H\&M, Zalando, Moncler, PUMA, Hugo Boss, Salvatore Ferragamo, YOOX Net-a-Porter Group, TOD'S, Brunello Cucinelli, GEOX, Van de Velde and Gerry Weber, among others. Beyond the division between fast fashion, luxury fashion and sustainable fashion, these companies have the broadest impact in terms not only of fashion consumption but also production due to their widespread supply chains. With greater understanding they therefore possess significant potential to minimise their negative impact while simultaneously positively impacting their whole value chain (Garcia-Torres et al., 2017). While sustainable fashion companies do not fall within the scope of the NFRD, a number voluntarily publish non-financial reports as part of their core business model and provide the core sustainability information the NFRD seeks from stakeholders in all industries (e.g. MUD Jeans, Living Crafts, allSisters, Patagonia). Tackling the sustainability hotspots discussed in Section 2 , these companies walk their talk without an external legislative impetus to do so. The question is why the fast fashion and luxury fashion companies are not striving to do the same, especially given that legislative obligations around the environmental and social considerations of business are well underway in the EU. The most obvious answer is that the predominant business models of both fast fashion and luxury fashion are inherently unsustainable. While luxury fashion is built on exclusivity and prestige that involves the use of unethical resources (e.g. fur, silk and labour outsourcing to further enlarge corporate profits) and environmentally unsound practices to keep the prices of their products high (e.g. incinerating unsold stock), fast fashion thrives on externalising negative environmental and social impacts, which allows them to produce and sell large quantities of garments for a low price. The formulation of the NFRD as it stands today allows for a cherry-picking approach, enabling the companies to determine for themselves what is material to report, making the non-financial reporting void in terms of its content and its ability to support a meaningful change towards more sustainable business practices. The following section analyses reports by three European "sustainability winners" in the three different categories (fast fashion, luxury fashion and sustainable fashion) to illustrate the shortcomings of the NFRD discussed in Section 3.

4.2.1. Fast fashion sustainability winners: a paradoxical situation. The cases of HEM, ZARA and CEA

H\&M has continually been identified as one of the world's most transparent and environmentally and socially sustainable fashion brands, despite belonging to the fast 
fashion industry and its business model of overproduction of low-cost clothing. By way of example, it has been recognised ten times as one of the world's most ethical companies by the Ethisphere Institute, been included in the Dow Jones Sustainability World Index for the seventh year in a row, ${ }^{10}$ ranking in the top $10 \%$ of global sustainability leaders, and ranked $27^{\text {th }}$ in Corporate Knights' annual ranking of the world's most sustainable corporations. H\&M was listed among the leading companies in Fashion Revolution's 2020 Fashion Transparency Index and is a part of the FTSE4Good Index Series. It has been recognised as one of the world's biggest users of recycled cotton, recycled wool, recycled nylon and lyocell. H\&M is also included in the Carbon Disclosure Project's 2019 Climate Change A List, which recognises the world's most pioneering companies in environmental transparency and performance. H\&M also ranked third in the Sustainable Cotton Ranking, which assesses how 77 companies score on their policy, traceability and actual uptake of sustainable cotton, and in Stand Earth's Filthy Fashion Scorecard, assessing the climate commitments of 45 fashion brands. Moreover, the Stockholm School of Economics' annual "Walking the Talk?" report on the sustainability communication of Sweden's largest listed companies named the H\&M Group as one of the best in terms of "walking the talk". As regards its policy on wages, H\&M was named the leading company in four categories (policy, integrating findings, tracking performance and transparency) in ASN Bank's 2019 “Living Wage in the Garment Sector" review. At the Corporate Responsibility Reporting Awards, the H\&M Group was the winner of the Creativity in Communication category and second place in the Openness \& Honesty, Relevance \& Materiality and Best Report categories. In terms of oneoff efforts, H\&M was awarded the PETA Vegan Homeware Award for Best Wool-Free Rug for its $100 \%$ recycled cotton patterned rug from its Conscious Collection. It may be claimed that H\&M has been selectively transparent, highlighting individual sustainable action that very modestly mitigates negative impacts, but even if such transparency were more material, transparency does not automatically translate to sustainability. By way of example, to be truly transparent, H\&M would have to report on its sustainability hotspots across its value chain and their mitigation, while in reality it provides information on their environmental and social policies and management in its annual non-financial report. To be truly sustainable, H\&M would need to change its production processes, comprised of high production volumes, quick turnaround times and low prices, which would not allow 4.3 billion garments worldwide to be discarded - a significant contribution to the creation of "throwaway culture". As NFRD only requires environmental matters to be disclosed "to the extent necessary for an understanding of the undertaking's development, performance, position and impact of its activity" (NFRD, Article 1.1), the corporation is free to focus

10. The Dow Jones Sustainability Indices (DJSI), the best-known measures of corporate environmental impact, were launched in 1999 as a family of indices evaluating the sustainability performance of thousands of companies and household names trading publicly, measured under a strategic partnership between S\&P Dow Jones Indices and RobecoSAM (Sustainable Asset Management). on the positive developments in terms of ameliorating its positive impact (or better said, diminishing its negative impact) compared to its benchmark of "business as usual", which is often not even their past performance but rather the performance of their peers "who are doing even worse" (Cline, 2013). Not linking the matters that must be reported on with scientific goals and international EU obligations in terms of climate action and sustainability challenges gives the paradoxical result of corporations reporting on their business model (in this case fast fashion) $)^{11}$ without needing to provide a clear plan for a holistic transformation of that model to tackle tonnes of their unsold clothes being incinerated each year (New York Times, 2018). This immaterial nature of H\&M's sustainability report actually complies with NFRD requirements, as it does give a brief description of the company's policies on matters of environmental and social sustainability and due diligence processes - their impact and size is irrelevant, as long as such policies and processes exist and are active.

The most promising requirement in the directive is that on the disclosure of "principal risks related to those [sustainability] matters linked to the undertaking's operations including, where relevant and proportionate, its business relationships, products or services which are likely to cause adverse impacts in those areas, and how the undertaking manages those risks" (NFRD, Article 1.1.d). This results in a mere acknowledgment of H\&M's negative sustainability impacts and very modest planned actions with no KPIs to quantify those plans, which are reported in a condensed version without truly allowing the actual transformation of H\&M's practices to be discerned on its core sustainability hotspots. ${ }^{12}$

The same considerations apply to Zara. Despite pledging to use $100 \%$ sustainable fabrics by 2025 (including recycled polyester and organic cotton), its sustainability strategy shows little promise, as the commitments are not supported by concrete actions, and the actions envisaged bring about unsustainable outcomes (e.g. mixing recycled polyester and organic cotton in the same sustainability strategy). Even disregarding the fact that a garment produced from organic cotton mixed with recycled polyester cannot be recycled, this particular sustainability strategy does not remedy the fact that the Inditex group of which Zara forms a part still produces 1.6 billion garments annually (Fashion Revolution, 2020). This volume not only requires enormous natural resources, but also results in a vast amount of waste due to overproduction.

11. H\&M Group (2020: 3): "We're exploring new business models, innovating with new materials and processes and collaborating with others to re-invent the fashion industry. And we believe that by taking a lead wherever we can and embedding sustainability throughout our culture, values and business, we will create a better customer offer for all our brands. We are proud of the journey we are on, but appreciate that there is a lot more work to do and much to learn".

12. H\&M Group (2020: 26): among its KPIs are "\% change in net $\mathrm{CO} 2$ emissions from own operations (scope $1+2$ ) compared with previous year, including renewables" and promises to be climate positive by the year 2040. However, in the last year emissions rose by $8 \%$, and no clear plan is in place to achieve climate positivity. On a similar note, the KPI of tonnes of garments collected through garment collecting initiatives does not answer the question of what happens to the collected garments. All of these issues stem from the business model itself and cannot be remedied by one-off actions. 
Much like the H\&M Group, Inditex is constantly receiving sustainability awards (e.g. most sustainable retailer according to the Dow Jones Sustainability Index; 5th in the FTSE4GOOD index; 4th place in the Spanish ranking Merco Responsabilidad y Gobierno Corporativo; and 205th place in Newsweek's Top Green Companies in the World), and yet its non-financial reporting reveals serious shortcomings in terms of sustainability and underlying transparency. With a final score of $43 \%$, according to the self-assessment-based Fashion Transparency Index 2020, its commitment to sustainable transformation is questionable, its non-financial report is of limited value and fails to provide the information required by the NFRD. While Zara scored remarkably high for the transparency of its policy and commitments (86\%), it also scored remarkably low for the traceability of its operations (19\%). This is alarming even in the absence of a more detailed analysis of Zara's non-financial report and is supported by the relatively low score for "walking the talk" (40\%).

The sustainability report is available only at the corporate group level, and shares many similarities with H\&M's. The assertion in the report that $63 \%$ of its global electricity consumption comes from clean sources highlights is not elaborated on in the report itself. Neither is the claim that $92.67 \%$ of their stores are eco-stores, beyond the information that A-rated energy efficiency air conditioning is to be installed across its stores. Claiming that sustainability is embedded in their products' entire life cycle and that designers will be trained on the circular economy by the end of 2020, the report does not show the simultaneous fall in clothes production that would attest to circularity being a true business objective, accommodating the longer garment-life and designs that facilitate repair and reuse. Neither is the information on the use of more sustainable fibres informative per se: the fact that recycled material use has been increased by $250 \%$ and that of sustainable cotton by $105 \%$ gives limited information on the allegedly diminishing negative environmental impact of such changes and no information at all about the future recyclability of garments produced by these materials.

As far as social sustainability is concerned, the launch of a new strategy is mentioned, as well as accompanying audits. Yet the outcome of the initiative remains unclear, especially as regards the social sustainability hotspots (e.g. forced labour, child labour, fair wages, etc.). Similarly, when it comes to the environmental sustainability of the supply chain, the aim of reaching the Zero Discharge of Hazardous Chemicals target in 2020 has not been met, with the report referring only to the commitment itself and to the creation of a list of existing chemicals (getting to know their own production processes, rather than implementing concrete actions to mitigate their negative environmental impact).

While Inditex prioritises the eco-efficiency of its head offices, logistics platforms, transport, distribution operations, websites and stores (with $92.67 \%$ of their owned stores complying with its Eco-Efficient Store Manual), this is unrelated to the core Inditex (and Zara) activities with the highest negative social and environmental impact. The report does not elucidate the actual mitigation of their total negative environmen- tal and social impact through those actions, especially given the modest reduction in energy use of these accompanying activities. It is safe to say that Inditex's reduction of scope 1 and 2 greenhouse gas emissions by $35 \%$ per $\mathrm{m} 2$ is due to their use of clean energy (63\% of their overall energy consumption in the year 2019).

The picture is even less clear when discussing circularity. The creation of a used clothing collection scheme in 2,299 stores in 46 markets is noted, but there is no information on how those garments re-enter the production chain. The reported data of using 14,000 tonnes of their own recycled cardboard as online sale boxes is uninformative: how is the recycling carried out? How are the online sales optimised to ensure optimal packaging? Add to that the information that $91 \%$ of waste generated in headquarters, logistics centres and factories were handled by experts, circularity does not seem to be ensured and Inditex's approach to circularity is very lacking in transparency. Last but not least, Inditex's philanthropic actions of donating clothing and employee volunteering by no means diminish their environmental and social impact. The issue of overconsumption, clothes waste and the manufacturing procedure per se is barely addressed, which may be said to be a total failure of Inditex's non-financial reporting.

C\&A, like the H\&M Group, has been considered a transparency winner, holding the second-highest score right after H\&M in the Fashion Transparency Index. It scores 97\% for disclosure on policies and commitments, $100 \%$ for disclosure on governance, $70 \%$ for traceability and $59 \%$ (the highest score awarded) for transparency on human rights and due diligence processes. Yet there is a stark difference between the sustainability approaches of H\&M and Inditex on one side, and C\&A on the other. In terms of circularity, beyond policy statements and commitments, C\&A has implemented and developed many circular practices, and changed their business model per se. In 2018 C\&A was the first European retailer to introduce Gold-level Cradle to Cradle Certified jeans; it developed the first Platinum-level Cradle to Cradle Certified denim fabric; and it verified in 2019 that $100 \%$ of its cellulosic fibre suppliers to Europe were low risk for the use of fibre from ancient or endangered forest products. While C\&A is also guilty of providing limited information regarding its recycled items (if they can be recycled again) and the percentage they comprise of C\&A production as a whole, and it is true that the data on the "We Take it Back" programme fails to explain where the garments end up, it has implemented a successful supply chain oversight programme, allowing it to know and mitigate its negative environmental and social impacts.

The company is taking a science-based approach to climate change adaptation, with concrete targets and actions to support its policies and commitments, thereby covering its environmental and social hotspots (as well scope 3 of $\mathrm{CO} 2$ emissions). C\&A also openly discusses its human rights violations, due diligence and concrete steps and audits undertaken to ameliorate the situation. Furthermore, its subsidiary in Brazil has been the pioneer in this kind of sustainable innovation: C\&A applied the same approach across its corporate group, leading by example outside of the EU. 
Understanding that the transition from a fast fashion company to an environmentally and socially sound business model cannot be carried out in a short time-frame, C\&A is an example of how a company can tackle its most relevant sustainability hotspots and "walk the talk", especially when compared to H\&M and Zara. While overproduction still needs to be tackled, as well as the content of their "We Take it Back" programme, its progress is documented, monitored and its actions closely follow C\&A's sustainability-related policies and commitments. But the transparent and clear C\&A non-financial report is not the source of C\&A's organic change, more the other way around: C\&A's organic commitment to sustainable transformation allows them to provide a coherent, relevant and material non-financial report, quite different from the general practice in the fast fashion industry.

\subsubsection{Luxury fashion sustainability winners: beyond greenwashing?}

Luxury fashion, due to its exclusivity and the use of high-quality material, has been seen as a lesser threat to sustainability than fast fashion. Yet the luxury fashion companies have also been criticised for their negative environmental and social impact (albeit sometimes for different reasons), and (pre-NFRD) they have rarely voluntarily disclosed their environmental and social impact in their annual reports. To that effect, the non-financial reporting practices of Kering, Moët Hennessy Louis Vuitton (LVMH) and Moncler will be analysed, allowing conclusions to be drawn on the nature of the influence of NFRD on luxury fashion, allowing for further suggestions for the revision of the NFRD.

Kering is a global luxury group, containing the brands Gucci, Saint Laurent, Bottega Veneta, Balenciaga, Alexander McQueen, Brioni, Boucheron, Pomellato, Dodo, Qeelin, Ulysse Nardin, Girard-Perregaux and Kering Eyewear. It created its 2025 sustainability strategy in 2017, aiming to reduce its environmental footprint by $40 \%$ through three pillars: care (reducing environmental footprint and preserving natural resources with the use of innovative tools), collaborate and create (innovative alternatives using an open source approach). As a member of the UN Global Compact, it integrates the ten principles into its business: supporting and protecting internationally proclaimed human rights and not being complicit in their abuse; upholding the freedom of association and effectively recognising the right to collective bargaining; eliminating all forms of forced and compulsory labour; effective abolition of child labour; elimination of discrimination in respect of employment and occupation; a precautionary approach to environmental challenges; undertaking initiatives to promote greater environmental responsibility; promoting greater environmental responsibility; development and diffusion of environmentally friendly technologies; and working against corruption. Furthermore, Kering developed its own sustainability principles, building further on its commitments under the UN Global Compact, while also acknowledging the applicable international conventions. Ten main themes have been determined for the indicators used to monitor Kering's environmental impacts through a web-based reporting tool: energy consumption, water consumption, waste production, paper consumption, packaging consumption, consumption of raw materials, transport (BtoB, BtoC and company cars), air pollution, environmental management, and general data on the site (surface area, turnover, etc.).
The existence of a methodological note to accompany Kering's non-financial report supports relevant transparency around the sustainability of its actions as it allows for comparability with the reports of other companies beyond the reported data itself. It also allows for the amelioration of the company's own methodology in assuring impact where the most action is needed to tackle corporate unsustainability. Kering is transparent about the scope of its reporting and the brands included, acknowledging the complexity of the task for large multinational conglomerates. Kering's main contribution to non-financial reporting is without doubt its sustainability manifesto, which urges accountability in the industry to be measured by a new profit and loss account - an environmental one - rolled out across all of its brands by the year 2016. The environmental profit and loss account measures environmental impacts across the entire supply chain, providing monetary values for these impacts. It enables comparisons to be made (both intertemporal and across the industry), incorporating environmental sustainability hotspots at the core of the fashion industry reporting: carbon emissions, water use, water pollution, land use, air pollution and waste. By translating environmental and social concerns into monetary values, the comparison between business years is facilitated, allowing for meaningful interpretation of progress in the light of the accompanying financial report. By way of example, their 2019 group environmental profit and loss account was stable compared to 2018, which represents substantial progress given "the steep increase of income on a pro-forma basis, the EP\&L intensity ( $€$ EP\&L per $€ 1000 \mathrm{rev}$ enue) decreased by 14\% between 2018 and 2019" (Kering, 2019c: 1). Kering reports not only on the combined outcomes, but also lays out the distribution of impacts across the supply chain, acknowledging that its most significant impacts are generated in the supply chain, in particular from the production and processing of raw materials. Kering's social sustainability actions are based on its "collaborate" approach, as reported in its Modern Slavery Statement for 2019. As with environmental sustainability, Kering ticks all the boxes on the social sustainability hotspots in the fashion industry through its due diligence approach - from fair wages to questions of diversity and general human rights questions.

LVMH is the leading global luxury products group, gathering 75 prestigious brands under its umbrella. Its analysis is indispensable to this chapter in the light of the fact that it operates (under the same strategy) in five large markets: wine and spirits; fashion and leather goods; perfume and cosmetics; selective retailing; and watches and jewellery. Its strong claim of "making sustainable development a strategic priority" calls for deeper scrutiny to be made of its practices and non-financial reports, especially as approximately half of its revenues derive from activities in the fashion industry. LVMH has made sustainable development a strategic priority since its founding. As early as 1992 it established an Environment Department, while Hennessy, one of its brands, launched the first analysis of a product's lifecycle. In 1995, the Perfumes \& Cosmetics Maisons created an ethno-botany department to protect species of plants used in cosmetics. In 1998, Hennessy was the first wine and spirits producer in the world to receive the ISO 14001 environmental certification and Cascade was deployed, a tool to assess the environmental footprint of the Maisons and prioritise action. In 
2001 LVMH produced its first ever environmental report in the luxury goods industry, and in 2002 it began trialling its process of $\mathrm{CO}_{2}$ emissions management. Like Kering, LVMH joined the Global Compact in 2003. Since then, LVMH has been continuously developing and ameliorating its sustainability policy and tools (e.g. developing its own standards and practices) and has been celebrated as the industry leader in sustainability.

LVMH separates its non-financial reporting into an Environmental Responsibility Report and a Social Responsibility Report. Both are incredibly detailed and as developed as their financial reports. In terms of environmental sustainability, LVMH took a scientific approach and developed LVMH Initiatives For the Environment, helping innovative answers to be given to questions in areas such as the environmental emergency, reducing the environmental footprint, protecting biodiversity, and so on. Its environmental performance is based on nine core elements: eco-design; secure access to strategic raw materials; traceability and compliance of materials and products; supplier environmental and social responsibility; preservation of critical skills; impact of $\mathrm{CO} 2$ from operations; environmental excellence; product lifecycle and reparability; and ability to answer customers' questions. This allows the most relevant scientifically defined environmental sustainability hotspots to be traced and measured. The report is centred around the achievement of four main objectives: a product objective (improving the environmental performance of all products); a sector objective (applying the highest standards in $70 \%$ of sourcing channels; $100 \%$ to be achieved in 2025); a CO2 objective (reducing emissions by $25 \%$ compared to the 2013 level, focusing primarily on stores); and a site objective (improving sites' key environmental efficiency indicators - water consumption, energy consumption and waste production - by at least 10\%). The detailed reporting on each of these aspects reveals that almost all of the targets have been achieved, allowing for further advances and ameliorations through new environmental goals. The report also outlays the certifications used to assure their supply chain is environmentally sustainable.

On biodiversity, more needs to be done, as they have not shied away from using the crocodile skin as a production input (or leather in general). Similarly, in terms of CO2 emissions, focusing solely on stores with a modest energy consumption decrease of $25 \%$ is some way short of science-based targets, which requires changes to the $\mathrm{CO} 2$ emissions in their supply chain. $\mathrm{LVMH}$ reduces $\mathrm{CO} 2$ emissions by upgrading industrial and administrative sites (by the end of 2019,60\% of the group's sites were ISO 14001 certified) and reducing the scope 1, scope 2 and scope 3 carbon footprints of transportation and raw materials. LVMH's approach is holistic: the focus on the environment has been one of its guiding principles for almost three decades, something that is also reflected in its non-financial reporting, remedying the shortcomings of the NFRD directive. Visualising their actions and contributions in a Sustainable Development Goals chart furthers the transparency and cross-industry comparability of their non-financial report.

The lesson to be learned from LVMH's environmental sustainability reporting is the need for focused transparency, addressing not only the sustainability hotspots of the fashion industry but continuously innovating and refining the approach towards mitigating negative environmental impacts. This should be embedded in the revised NFRD.

The same applies to social sustainability reporting, which is based on four priorities: respecting the uniqueness of their employees; passing on and developing savoir-faire; supporting its employees by improving their safety and well-being; and empowering local communities. In terms of actions supporting diversity, LVMH works in several thematic fields: it promotes diversity and fosters inclusion at work; improves equality and promotes career development for women (75\% of LVMH's workforce); supports people with disabilities into work; and structures knowledge transmission around older employees to harvest existing knowledge. To facilitate the passing on and developing of savoir-faire, LVMH recruits talent to safeguard the future of tradition; contributes to the continuity of savoir-faire (preserving high quality while ensuring sustainable outcomes); and develops employee skills throughout their entire career. In terms of improving employees safety and wellbeing, LVMH protects the wellbeing of employees by placing their motivation and work-life balance at the heart of their excellence-oriented approach; by improving health and safety at work across their supply chain; and by encouraging dialogue across the corporate structure. In terms of empowering local communities, LVMH plays an active role in the communities in which it operates by injecting growth, innovation and employment; it creates employment opportunities and economic momentum; it aids the re-inclusion of the long-term unemployed and young people into work; and it supports vulnerable populations through philanthropy. As with their environmental reporting, their social sustainability reporting also includes a graphical representation in terms of the Sustainable Development Goals. But, in contrast to its environmental sustainability reporting, LVMH gives less attention to social sustainability hotspots in its report, suggesting that the supply chains are as socially sustainable as they claim to be, without direct intervention by LVMH to ameliorate the challenging situation in terms of the social sustainability of fashion in general.

Moncler, the last company analysed in this subsection, is originally a French company that is currently headquartered in Italy and produces high-level outerwear collections that are unique products of the highest quality - "timeless", versatile and innovative. Moncler takes sustainability very seriously: it was named a textiles, apparel and luxury goods "industry leader" in the Dow Jones Sustainability Index the first time it was included in the ranking, showcasing how slow fashion based on natural materials can achieve industry standards while being socially and environmentally sustainable. For social sustainability (human rights, human capital development and health and safety) it scored 85 (against an industry average of 32) and 92 for environmental sustainability (product stewardship, operational eco-efficiency and environmental policy and management systems) against an industry average of 41 .

Moncler's consolidated non-financial statement reports on its responsible business management in terms of its governance model, risk management, sustainable value creation and sus- 
tainability plan, providing a holistic overview of the sustainable actions that provided the results included in the report. Its sustainability governance is carried out through a separate sustainability unit, which created Moncler's own materiality matrix as an expression of its sustainability hotspots and defined Moncler's stakeholders and their engagement in detail. The Born to Protect Sustainability Plan expresses commitment to an increasingly sustainable and responsible long-term development through five priority commitments: fighting climate change, integrating a circular economy model, promoting a responsible supply chain, fostering inclusive collaborations, and giving back for the social and economic development of local communities. On climate change, it has achieved 100\% renewable energy in its facilities in Italy and is aiming for $100 \%$ renewable energy at the global level by 2023 and carbon neutrality for its operational sites by 2021. These goals are coupled with actions for achieving energy efficiency and transport emissions monitoring.

In terms of circular economy principles, Moncler has launched a Life Cycle Assessment project while simultaneously including the use of recycled materials in its production and eliminating dangerous substances from its production processes. To give it further substance, Moncler is launching Extra lift repair services globally as well as the Take Me Back global project to extend products' life, while simultaneously mitigating the environmental impact of its packaging. When it comes to responsible sourcing, the progress reported is very modest and requires further attention. In the framework of the promotion of fair workplaces, the required supplier mapping is taking place, supporting further work on responsible sourcing. Despite being presented as a sustainability leader in the field of luxury fashion, Moncler's non-financial report raises very similar concerns to the non-financial reports of fast fashion companies: not all the company's sustainability hotspots are noted, and those issues that are disclosed show limited transparency.

While Moncler seems to be setting out on the sustainability path, defining its sustainability hotspots and trying to find where and how to start, Kering and LVMH have already made substantial progress on the matter, at least in terms of defining their sustainability hotspots, priorities for action and mapping their global supply chains as a pre-condition for meaningful action. While Kering, as a sustainability leader in the luxury fashion industry, approaches environmental and social sustainability in great detail, allowing for intertemporal and corporate comparability of the data, LVMH should replicate its approach to environmental sustainability in its social sustainability.

It might, intuitively, be expected that the inherent characteristics of the business models in luxury fashion allow it to embed sustainability in the existing structures without the need for deep restructuring and that this would decrease the need for greenwashing. But the analysis of the actions and reporting of three separate luxury fashion companies shows that this depends on the company and whether they have embedded sustainability as a core principle in their business model. Where they achieve this, the reporting and action follow suit and are relevant and comparable, where they do not, similar challenges arise as in fast fashion companies.

\subsubsection{Sustainable (ethical) fashion: role models for the NFRD revision?}

To meaningfully conclude the present section on non-financial reporting in the fashion industry, the present subsection analyses the functioning and the sustainability reporting of sustainable (ethical) fashion companies. Created and guided by sustainability as their core business rationale, they have an inherent need for heightened and focused transparency and timely communication about their sustainable actions to their stakeholders. The analysis of three European companies, namely Patagonia, Armed Angels and MUD Jeans, will conclude Section 4, and serve as a role model for the revision of the NFRD.

While Patagonia is not an EU-based company, it represents a textbook example of a forward-looking sustainable business model in fashion, and its reporting practices follow suit. Patagonia is a US-based clothing company founded in 1973 that markets and sells outdoor clothing - "in business to save our planet". In 2012 Patagonia became a Certified B Corporation, a for-profit company that meets "rigorous standards of social and environmental performance, accountability, and transparency" (Certified B Corporation, 2019). Patagonia considers itself an "activist company", always innovating on sustainable practices that can be embedded in its practices to minimise their negative environmental and societal impact (it innovates even in the field of family / maternity leave policies). Beyond its core business practices, Patagonia commits $1 \%$ of its total sales to environmental groups through 1\% for the Planet, and in 2016 it passed on $100 \%$ of sales from Black Friday to environmental organisations. It also actively advocates for sustainable business practices through its political engagement, acting as a global industry leader. ${ }^{13}$ In 2018 the company even donated the $\$ 10$ million it received from tax cuts to "groups committed to protecting air, land and water and finding solutions to the climate crisis" (Adweek, 2018). Patagonia boycotted Facebook and Instagram advertising after it entered a US civil rights boycott movement, using its corporate power for the greater good.

In terms of sustainable corporate practices, Patagonia has adopted six specific benefit purpose commitments: $1 \%$ for the Planet, Build the Best Product with No Unnecessary Harm, Conduct Operations Causing No Unnecessary Harm, Sharing Best Practices with Other Companies, Transparency, and Providing a Supporting Work Environment. Its corporate reporting follows suit and is divided into these six sections. The category "Build the Best Product with No Unnecessary Harm" reports on its apparel material sources, environmental certification(s), product care and repair guides, global repair centres and supplier policies. Aside from reporting on

13. In 2017 Patagonia led a boycott of the Outdoor Retailer trade show, which traditionally took place in Utah, after the Utah state legislature introduced legislation that would transfer federal lands to the state. Patagonia also opposed Utah Governor Gary Herbert's request that the Trump administration revoke the recently designated Bears Ears National Monument in southern Utah. After several companies joined the Patagonia-led boycott, event organiser Emerald Expositions said it would not accept Utah's proposal to continue hosting the Outdoor Retailer trade show and would instead move the event to another state. 
its highlights (becoming a climate-neutral company, raising the product quality bar, closing the loop with worn wear, collection made from recycled and solution-dyed materials, long root beer, regenerative organic certification pilots, paying a living wage throughout the supply chain), it also objectively reports on the remaining challenges (e.g. increasing its footprint even as it decreases the use of virgin materials and implements garment recycling). This distinguishes Patagonia from the sustainability reporting of the large fast fashion conglomerates.

In the category "Conduct Operations Causing No Unnecessary Harm" Patagonia describes its commitment to becoming carbon neutral by 2025; its practice of sourcing $100 \%$ renewable electricity for its owned and operated facilities in the US; its $100 \%$ use of recyclable retail store receipt paper; its global electricity use and scope 1 and 2 carbon emissions. While it has reported a growth in the use of electricity and scope 1 and 2 carbon emissions, it has also worked on making its global facilities run on $100 \%$ renewable energy, tackling the inherent trade-offs of achieving truly sustainable outcomes (as it also has in terms of going zero-waste).

In the section "Sharing Best Practices with Other Companies" Patagonia reaches beyond its own transition and progress and aims to aid other enterprises embedding best practices into their own operations. It reports on investments in other responsible businesses, the amount of fishing nets repurposed into Patagonia products and speaking engagements, among other activities. This part of the corporate report discusses the regenerative organic certification, the $\mathrm{B}$ Corp Climate Leadership Summit and notes the challenges with developing its own standards for adoption.

On transparency, Patagonia notes its longstanding tradition of disclosing its suppliers, having an active blog revealing new facts on unsustainable corporate practices and the annual Patagonia competition for students to propose solutions to lessen the environmental impact of single-use packaging for apparel and food products by 2025 . It also reports on actively engaging in solving the issue of microfibres and their reduction, publishing guidelines for reducing microfibre shedding at home. Patagonia furthers its transparency practices by aligning its Tier 1 suppliers with the criteria of the Transparency Pledge Coalition, publishing a standardised list of factories with meaningful information.

In "Providing a Supportive Work Environment" it reports on the company's advanced maternity and paternity leave policy, gender equality, and highlights its environmental internships and Earth University to create lifelong stewards of the planet, while noting the challenges of rising housing costs and a living wage. While the non-financial reporting by Patagonia is more aligned with BCorp than NFRD reporting, the comprehensive issues inherent in its sustainability report are highly informative about which information should be revealed by fashion companies to allow for the understanding of the actual impact of their business practices in environmental and social terms. The biggest lesson for the NFRD revision that can be taken from the Patagonia example is the transparency about the achievements and re- maining challenges, together with the accompanying plans for amelioration.

The second company analysed, Armed Angels, is a German fashion label established in 2007 that designs a variety of garments made from sustainable textiles, selling them online and in-store in six countries. It seeks to compete with mainstream fashion, producing sustainable fashion that is simultaneously ethical and fashionable, and changing the perception that eco-friendly clothing is unfashionable. Being supply-chain aware, Armed Angels collaborate only with socially responsible companies that are fair-trade certified. Its corporate philosophy is built on three main pillars: being good to the environment, supporting fair trade and donating to charity. This is illustrated by the use of organic cotton in their clothing, avoiding large shipping distances to reduce $\mathrm{CO}_{2}$ emissions, paying more than minimum wage to its farmers in India and donating a euro of profits from every piece of clothing sold. These inherent characteristics of Armed Angels' business model are also visible also in their non-financial reporting. The achievements are set out at the beginning of the report, the focus being on water, energy, CO2 savings and their circularity efforts, directly addressing the environmental sustainability hotspots of the fashion industry as a whole.

As regards social sustainability, the beginning of the report immediately addresses the company's supply chain, setting out the actions carried out in the 2019 business year. In terms of sourcing practices, the company reports on its responsible sourcing and pricing, setting out the responsible on-boarding, true pricing, the goal of providing living wages and fair pricing, as well as addressing its production cycle, monitoring activities and subcontracting, outlining its best practices and challenges, providing a transparent and balanced account of the challenges facing the fashion industry and the company.

While the company is not a large conglomerate, this does not mean that the form and content of its reporting could not also be used also in a big company, especially given the fact that large corporate groups consist of many subsidiaries, which are able to produce such reports by themselves. It could be argued that obtaining all the necessary information requires major investment and substantial additional human resources, yet such knowledge and tackling corporate environmentally and socially unsustainable practices will shortly be required of EU companies by virtue of the upcoming revision of the EU corporate law framework.

The third fashion company whose best practices are relevant in terms of sustainable fashion and non-financial reporting is MUD Jeans, a sustainable and fair-trade certified denim brand from the Netherlands, founded on the principles of the circular economy. It aims at radically changing the fashion industry by taking the most popular fashion item in the world -jeans - and producing them in the most sustainable way without losing a timeless sense of style, allowing consumers to participate in the sustainable transition of the fashion industry.

Using discarded denim, their jeans are made from $40 \%$ recy- 
cled content, and the final products are leased to consumers. After a year, the consumers can switch the jeans for another pair and continue leasing, return them for recycling or upcycling purposes or keep them, with the lease entailing free unlimited repair services (the Lease A Jeans concept). MUD Jeans sells its products online and through a limited number of sustainable concept stores around the globe. The analysis of its non-financial reporting practices is important due to the companies' circular business model, which further minimises the negative environmental and social impact of fashion through the business model itself.

The company reports substantial savings in terms of water consumption (300 million litres of water less in the last three years), CO2 production (avoiding 700,000 kilos of CO2 in the last three years) and waste (12,000 pairs of jeans saved from landfill and incineration in the last three years). Its reporting format follows its business model by providing information on targeted impacts, outlaying prima facie the positive environmental impact of the business practices in which it engages. MUD Jeans reports on innovation in terms of providing $100 \%$ recyclable garments, actively working on a social audit on the wage situation and going beyond climate neutrality, pioneering and ameliorating its sustainable business model and thereby indirectly revealing the remaining challenges regarding sustainability in the fashion industry. They are a small company that has experienced impressive growth and can share their experiences with the larger fashion players. Supporting circular consumption is their strength, but aside from focusing on circular consumption they simultaneously tackle their sustainability hotspots across their operations and are highly transparent about those practices too. Organic engagement is the lesson to be learnt from their corporate and non-financial reporting practices.

\section{The strengths and the pitfalls of the NFRD: where could we do better?}

As highlighted before, the aim of the NFRD is to "improve undertakings' disclosure of social and environmental information", as this disclosure "is vital for managing change towards a sustainable global economy by combining long-term profitability with social justice and environmental protection" and "helps the measuring, monitoring and managing of undertakings' performance and their impact on society". The directive is supposed to enhance the consistency and comparability of non-financial information disclosed across the EU, at a minimum achieving the provision of a "description of the policies, outcomes and risks related to those matters", accounting also for supply and subcontracting chains to identify, prevent and mitigate existing and potential adverse impacts. The analysis carried out in this work aligns with the opinion of the Commission that these aims have yet to be achieved.
Considering the existing reporting practices in the fashion industry, the aims of the EU Green Deal in terms of achieving net zero greenhouse gases in 2050 and decoupling the economic growth from resource use in general, and the EU strategy for sustainable textiles - particularly concerning microplastics and circular efforts - the suggestions for the NFRD revision from the lessons learned in the fashion industry should aim at an ambitious overhaul of the initial directive to ensure policy coherence on the sustainability of the fashion industry.

\subsection{The strengths of the NFRD as applied in the fashion industry}

The most relevant contribution of the NFRD's introduction into the EU legal order has been to incentivise large EU enterprises that had been postponing their transition towards more sustainable practices and to understand their environmental and social impact. Both fast fashion and luxury fashion companies have been transformed in terms of their focus on sustainability and understanding of the structure of their business beyond financial considerations. Despite the varied, non-comparable and selective information on their non-financial impacts, the companies created their own frameworks and mapping of their impacts as an excellent starting point. This also spurs internal discussions and corporate reorganisation to adhere to the new reality and the consumer and legislative requirements. This initial step towards meaningful non-financial reporting also served as a trial-and-error exercise for the EU legislator, as it allowed not only the NFRD shortcomings to be pinpointed, but also informed future policymaking in the field of corporate sustainability in the EU (e.g. sustainable corporate governance, due diligence, carbon taxation, etc.). By introducing mandatory non-financial reporting in the EU for large entities, the NFRD spurred a "sustainability competition" between companies in the EU in general - although in terms of fashion companies it seems to have resulted in a self-sustaining greenwashing competition, supported by the transparency and sustainability rankings in the field. Nevertheless, despite these shortcomings, the companies in the fashion industry have also started paying attention to their supply chains and their business practices, which will hopefully help avoid Rana Plaza-like catastrophes (Jacobs and Singhalb, 2017), as companies should now closely follow their whole supply chain and assure sustainability across them in their entirety.

\subsection{The weaknesses of NFRD as applied in the fashion in- dustry}

As the NFRD Impact Assessment notes, irrespective of the industry in question, the information disclosed by companies does not meet the needs of stakeholders. It does not adequately detail how non-financial issues and sustainability in particular impact companies and how those companies in turn impact society and the environment. The reported in- 
formation is not sufficiently comparable or reliable; companies do not report all non-financial information users think is necessary; some companies simply omit the negative impact information; it is hard for stakeholders to find non-financial information even where reported; and companies face uncertainty and complexity when deciding what non-financial information to report. While there have been calls to use science-based targets to that effect (Climate Disclosure Project, 2020), they have not been extensively employed in the non-financial reporting practices. The EU Commission therefore aims to provide further direction to corporates under the revised NFRD so that reliable, comparable and relevant non-financial information can be disclosed.

What can be suggested, based on the existing scholarship and the present work, is that scientific findings on sustainability hotspots in the fashion industry should be used to ensure a meaningful framework for corporate reporting. At a minimum, each company in the fashion industry should report on the following: $\mathrm{CO}_{2}$ emissions traced and mitigated; deforestation; water management; loss of biodiversity; chemical and water pollution; the use of pesticides and fertilisers; energy sourcing and consumption; the use of circular practices; waste creation and management; and advanced practices (minimising the impact in terms of material use, energy use, recycling) across their entire supply chain. While some companies will be building on their already established practices, others that have yet to embark on this path will find it challenging to create the initial framework in their company or their corporate group. The argument that the initial investment on knowing your impact does not outweigh the related benefits is obsolete in the light of the market pressures and the EU policies on sustainable corporate conduct, which do not allow for selective reporting and general corporate non-accountability.

These sustainability hotspots for individual industries could be attached to the revised direction in the form of an informative but not exhaustive annex that allows for flexibility but not complete corporate discretion. After determining the sustainability hotspots, under a still flexible reporting framework, each company should determine their priorities in terms of mitigating their negative environmental and social impacts in the most efficient way. This responsibility and accountability are further facilitated by the EU's sustainable corporate initiative, which will insert sustainability into corporate governance not only as a guiding principle, but also as a possible director responsibility. The existing tools and approaches for quantifying the relevant information and the diverse sustainability assessment frameworks available on the market (public and private) facilitate the measuring of individual corporate impact. On a similar note, sourcing leather, wool and fur in the fashion industry should be addressed wherever those practices remain in place, with at least an accompanying explanation as to why those materials cannot be substituted with more sustainable alternatives.

Targets should be set in accordance with EU Green Deal targets, and not in an individual manner. This requirement should be inserted into the revised NFRD, requiring the alignment of individual corporate targets with collective EU targets, wherever they are unequivocally set. Not addressing the inherent pitfalls of your business model should be nei- ther allowed nor accommodated by the revised NFRD. After this material revision of the substance of the reporting itself, the recommendations made by the respondents to the NFRD consultation should be answered by requiring the MS to impose penalties on corporations and corporate directors to enhance the enforcement of the obligations under the NFRD. This has proven to be challenging and was considered one of the main impediments to a more meaningful implementation of the NFRD. Last but not least, the non-financial report should be easily accessible to all stakeholders - this should be a requirement for the report to be considered compliant with the NFRD. It should also contain an obligatory executive summary that allows for a clear understanding of the company's impact and progress in terms of sustainability.

\section{The way ahead: suggestions for the future}

The state of the art in fashion on social and environmental sustainability, as portrayed in the present work, calls for a more structured and firmer legislative approach to regulating corporate behaviour in the industry. The market is slow to answer customers' sustainability-related demands and nudging towards more sustainable behaviour has not borne much fruit. The size of the apparel companies with the greatest market power and their respective global markets mean individual national actions are of limited effect. They are also rarely very ambitious, as they bring an initial, short-term disadvantage to the national market, where doing business inevitably becomes more costly than in other jurisdictions.

The analysis of the sector and its environmental and social impacts suggests the need for a more science-based approach through a re-definition of business law policies, which should be informed by a change in the reporting requirements and standards that guide the form and content of the transformation of the fashion business towards a more environmentally and socially sustainable format. By way of example, while some fashion companies have already begun to tackle sustainability-related issues through their existing corporate social responsibility departments, others have found themselves left with the demanding task of core business transformation without the knowledge, tools and understanding of which challenges are of critical importance and where the transformation should start. The findings of the present work suggest that a focus on "making any difference" in terms of their environmental and social sustainability should be replaced by "making the difference required". Here, the regulation on non-financial reporting is of utmost importance, as it not only allows the correct and relevant information to reach the consumers and policymakers, but serves as a guiding principle for the companies that start engaging in the practice of sustainable transformation.

The more stringent requirements of amended non-financial reporting at EU level provide more clarity on where negative impacts might lie, ensuring that the correct indicators will be considered, instead of marginal environmentally friendly practices. Any developments in the field of non-financial and sustainability reporting should follow a science-based approach - focusing on the most damaging, non-sustainable aspects (in social and environmental terms) of the specif- 
ic fashion company across its supply chain, as determined in relevant research, ensuring that marginal and irrelevant sustainability-related information remains part of the less significant corporate social responsibility practices. As it has been important for the EU and its MS to insert the notion of non-financial sustainability reporting into policymaking and in the form of mandatory legislation, the revision of the NFRD should be based on such a scientific approach (and it has been to a certain extent, as seen in the recent Proposal for a Corporate Sustainability Reporting Directive).

These changes not only presuppose a significant effort from the management to carefully map the corporate unsustainable impact across its supply chain, but also an effort to mitigate that impact and minimise it, in order to keep the company competitive in the midst of the market changes we are currently witnessing. Furthermore, after the modest regulation of sustainability reporting at EU level, which only required reports from entities of a specific size, the next step for achieving a sizeable impact on sustainable corporate behaviour is to also require such reports from smaller entities, which are often the suppliers of the larger corporate entities. If applied to the fashion industry, this will result in the transformation of the whole supply chain, which is necessary if true sustainability is to be achieved in the industry: the most significant negative impacts in fashion companies are found across their supply chains. Aside from these top-down international developments, policy and legislative changes at the level of individual EU MS can give further content to the requirements of the supranational instruments, further strengthening the framework and guiding the content and form of corporate transformation in the fashion industry.

In line with the abovementioned considerations, non-financial reporting in the fashion industry seems likely to grow, given the national legislation enacted across the EU on the matter in the last few years. For example, a new French law prohibits the destruction and unnecessary waste of unsold clothing: the Bill on the fight against waste and the circular economy requires the fashion companies to abide by more than 100 sustainable inputs. Among others, the law requires producers, importers and distributors, including e-commerce platforms, to donate unsold non-food goods - except those that pose a health or safety risk - or face fines of up to $€ 17,000$. It also requires companies to pay for the destruction of the waste they create under the "polluter pays" principle. These provisions are directly disincentivising corporate overproduction and imposing specific sustainability obligations on French companies with corresponding sanctions, ensuring effective enforcement of this new legislative framework.

Aside from the national implementation of NFRD, several climate and circular economy laws have been passed across the EU MS that impose further corporate sustainability obligations. EU legislation should accompany these national developments, ensuring policy coherence exists for sustainability at both supranational and national levels: the minimum requirements entailed in the revised NFRD should by no means be maximal harmonisation as understood by EU law. The pressure in terms of the revised NFRD is currently alleviated to a certain extent, as the transformation of EU and national corporate law frameworks to account for sustainability and require sustainable corporate practices enhances and further contextualises and defines the reporting obligations under the NFRD.

The fashion industry should, the scientific findings show, first and foremost target the sourcing and manufacturing phase, as more than $90 \%$ of the fashion industry's total global climate change impact can be attributed to fibre and fabric production, yarn preparation and dying. This will undoubtedly raise the price of fast fashion and naturally allow for less overconsumption and overproduction, resulting in more sustainable consumer attitudes towards fashion consumption. As this change is inevitable in the light of recent scientific findings on the changed environment for fashion companies in terms of resource scarcity and climate change (Steffen et al., 2015), and in the light of civil pressure to ensure environmental and social sustainability, if they wish to assure their position in the newly developing business environment companies are advised to be the first movers rather than latecomers to this transition train. If the companies in the fashion industry want the new legislative framework to be better adapted to their needs and requirements, it would be advisable for them to embark on the path towards sustainable transition themselves. They would then be better placed to inform the legislators of the best approach to legislation based on their own best practices. This path has been underused and gone somewhat unnoticed by the fashion companies, but it could actually prove to be the most mutually beneficial of all.

\section{References}

\subsection{Legislation}

European Commission, Communication from the Commission, Guidelines on non-financial reporting (methodology for reporting non-financial information) C / 2017 / 4234, OJ C 215, 2017.

European Commission, Communication from the Commission to the European Parliament, the European Council, the Council, the European Economic and Social Committee and the Committee of the Regions, The European Green Deal $\mathrm{COM} / 2019 / 640$ final, 2019a.

European Commission, Communication from the Commission, Guidelines on non-financial reporting: Supplement 
on reporting climate-related information C/ 2019/4490, OJ C 209, 2019b.

European Commission, Communication from the Commission to the European Parliament, the Council, the European Economic and Social Committee and the Committee of the Regions, A new Circular Economy Action Plan For a cleaner and more competitive Europe COM/2020/98 final, 2020a.

European Commission, Communication from the Commission to the European Parliament, the European Council, the Council, the European Economic and Social Committee and the Committee of the Regions, A New Industrial Strategy for Europe COM/2020/102 final, 2020b.

European Commission, Commission Staff Working Document (2020) Identifying Europe's recovery needs accompanying the document Communication from the Commission to the European Parliament, the European Council, the Council, the European Economic and Social Committee and the Committee of the Regions (2020) Europe's moment: Repair and Prepare for the Next Generation SWD/2020/98 final, 2020c.

European Commission, Communication from the Commission to the European Parliament, the European Council, the Council, the European Economic and Social Committee and the Committee of the Regions. Europe's moment: Repair and Prepare for the Next Generation COM/2020/456 final, 2020d.

European Commission, Inception Impact Assessment: Revision of the Non-Financial Reporting Directive, Ref. Ares(2020)580716, 2020e.

European Commission, Inception Impact Assessment on Sustainable Corporate Governance Ref. Ares(2020)403403, $2020 \mathrm{f}$.

European Commission, EU Strategy For Sustainable Textiles, Ref. Ares(2021)67453, 2021 (online). [Accessed on 09.06.21]: https: / / ec.europa.eu/info/law/ better-regulation/have-yoursay / initiatives/12822-EU-strategy-for-sustainable-textiles_en

European Parliament, Directive 2013/34/EU of the European Parliament and of the Council of 26 June 2013 on the annual financial statements, consolidated financial statements and related reports of certain types of undertakings, amending Directive 2006/43/EC of the European Parliament and of the Council and repealing Council Directives 78/660 / EEC and 83/349/EEC OJ L 182, 2013.

European Parliament, Directive 2014 / 95 / EU of the European Parliament and of the Council of 22 October 2014 amending Directive 2013/34/EU as regards disclosure of non-financial and diversity information by certain large undertakings and groups OJ L 330, 2014.

European Parliamentary Research Service, Corporate due diligence and corporate accountability: European added value assessment PE 654.191, 2020.

Federal Republic of Germany, Gesetzzur Einführung eines Bundes-Klimaschutzgesetzesund zur Änderung weiterer Vorschriften, 2019.
European Parliament, Proposal for a Directive of the European Parliament and of the Council amending Directive 2013/34/EU, Directive 2004/109 / EC, Directive 2006 / 43 / EC and Regulation (EU) No 537/2014, as regards corporate sustainability reporting COM/2021/189 final, 2014.

European Parliament, Regulation (EU) 2016/1011 of the European Parliament and of the Council of 8 June 2016 on indices used as benchmarks in financial instruments and financial contracts or to measure the performance of investment funds and amending Directives 2008 / 48 / EC and 2014/17/EU and Regulation (EU) No 596/2014 and Regulation (EU) 2019/2089 of the European Parliament and of the Council of 27 November 2019 amending Regulation (EU) 2016/1011 as regards EU Climate Transition Benchmarks, EU Paris-aligned Benchmarks and sustainability-related disclosures for benchmarks PE/90/2019/ REV / 1, OJ L 317, 2019a.

European Parliament, Regulation (EU) 2019/2088 of the European Parliament and of the Council of 27 November 2019 on sustainability-related disclosures in the financial services sector PE / 87 / 2019/REV/1, OJ L 317, 2019 b.

European Parliament, Regulation (EU) 2020/852 of the European Parliament and of the Council of 18 June 2020 on the establishment of a framework to facilitate sustainable investment, and amending Regulation (EU) 2019/2088 PE/20/2020/INIT, OJ L 198, 2020.

Republic of France, "La loi énergie et climat du 8 novembre 2019 vise à répondre à l'urgence écologique et climatique”, 2019.

UK Parliament, "Fixing fashion: clothing consumption and sustainability", Sixteenth Report of Session 2017-19, 2019.

\subsection{Articles}

Adweek, "Patagonia Will Donate the \$10 Million It Saved From Tax Cuts to Environmental Groups Continuing its history of charitable endeavors", 2018 (online). [Accessed on 09.06.21]: https: / / www.adweek.com/brand-marketing/patagonia-will-donate-the-10-million-it-saved-from-tax-cutsto-environmental-groups /

Alliance for Corporate Transparency, 2018 Research Report: The state of corporate sustainability disclosure under the EU Non-Financial Reporting Directive, 2019.

Armed Angels, Social Report 2019, 2019 (online). [Accessed on 09.06.21]: https: / / www.armedangels.com/media/97/ ff/9c/1596112531/ ARMEDANGELS_Social-Report_2019. pdf

Arriga, E. "Corporate Sustainability in Fashion and Luxury Companies", Symphonya. Emerging Issues in Management Special Issue on Fashion and Luxury Management, 4, 2015, pp. 9-23 (online). [Accessed on 06.06.21]: http://dx.doi. org/10.4468/2015.4.02arrigo.

Bain \& Company, "Brief: Luxury after Covid-19: Changed for (the) Good?", 2020 (online). [Accessed on 09.06.21]: https:/ / www.bain.com/insights/luxury-after-coronavirus / 
BBC News, "The North Face and Patagonia boycott Facebook ads", 2020 (online). [Accessed on 09.06.21]: https://www. bbc.com/news/technology-53137877

Bick, R., Halsey, E. and Ekenga, C. C. "The global environmental injustice of fast fashion" Environmental Health, 17:92, 2018 (online). [Accessed on 09.06.21]: https:// doi. org /10.1186/s12940-018-0433-7.

Burberry, Burberry Annual Report 2017/18, 2018 (online). [Accessed on 09.06.21]: https://www.burberryplc.com/ content / dam / burberry / corporate / Investors / Results_Reports / 2018/Burberry_AnnualReport_FY17-18.pdf

C\&A, Making Sustainable Fashion the New Normal: Global Sustainability Report 2019, 2020 (online). [Accessed on 09.06.21]: https: / / sustainability.c-and-a.com/uk/ en/ sustainability-report/2019/

Cambridge Dictionary (online) [Accessed on 10.06.21]: https: / / dictionary.cambridge.org / dictionary / english / fast-fashion

Certified B Corporation, "Patagonia B Impact Report", 2019 (online). [Accessed on 09.06.21]: https://bcorporation.uk/ directory/patagonia-inc

Cervellon, M. C., Hjerth, H., Ricard, S., and Carey, L. “Green in fashion? An exploratory study of national differences in consumers concern for eco-fashion", 2010 (online). [Accessed on 09.06.21]: https://researchonline.gcu.ac.uk/en/publications/ green-in-fashion-an-exploratory-study-of-national-differences-in-

Climate Disclosure Project, Science Based Targets: Disclosure Insight Action - Foundations for Science Based Net-Zero Target Setting in the Corporate Sector, 2020.

Cline, E. L., Overdressed: The Shockingly High Cost of Cheap Fashion, Penguin Group, 2013.

CNBC, "Luxury retailer Neiman Marcus files for bankruptcy as it struggles with debt and coronavirus fallout", 2020 (online). [Accessed on 09.06.21]: https://www.cnbc. com / 2020 / 05 / 07 / neiman-marcus-files-for-bankruptcy.html

Ellen MacArthur Foundation, A New Textiles Economy: Redesigning Fashion's Future, 2017 (online). [Accessed on 09.06.21]: https://www.ellenmacarthurfoundation.org/ publications / a-new-textiles-economy-redesigning-fashions-future

Ellen MacArthur Foundation, Vision of a circular economy for fashion, 2020 (online). [Accessed on 09.06.21]: https:// www.ellenmacarthurfoundation.org / assets / downloads/Vision-of-a-circular-economy-for-fashion.pdf

Environmental Protection Agency, "Advancing Sustainable Materials Management: 2014 Fact Sheet", 2014 (online). [Accessed on 09.06.21]: https://www.epa. gov / sites / production / files / 2016-11 / documents / 2014 smmfactsheet_508.pdf
Fashion United Top 100 Index (online). [Accessed on 09.06.21]: https: / / fashionunited.com/i / top100/

Fashion Revolution, Fashion Transparency Index 2020 Edition, 2020 (online). [Accessed on 09.06.21]: https://www. fashionrevolution.org/about/transparency /

Feedbacks on Non-financial reporting by large companies:

Asociación Española de Directivos de Responsabilidad Social-DIRSE response to the Public consultation on the revision of the nonfinancial reporting directive (online). [Accessed on 10.06.21]: https://www.dirse.es/wp-content / uploads / 2020 / 06 / 200611-Contribution9ec02ed0-b2 83-4b22-8885-6d5076bc8382.pdf

Autorité des marchés financiers (AMF) Feedback on Non-financial reporting by large companies (online). [Accessed on 10.06.21]: https:/ / ec.europa.eu/info/law/better-regulation / have-your-say / initiatives / 12129-Non-financial-reporting-by-large-companies-updated-rules-/ F506627_en

CDSB response to Inception Impact Assessment on the Revision of the Non-Financial Reporting Directive (online). [Accessed on 10.06.21]: https: / / www.cdsb.net/sites/default / files/cdsb_response_to_nfrd_inception_impact_assessment.pdf

Client Earth's response to the roadmap consultation for the inception impact assessment of the revision of the Non-Financial Reporting Directive (online). [Accessed on 10.06.21]: https:/ / ec.europa.eu/info/law / better-regulation / have-your-say / initiatives / 12129-Non-financial-reporting-by-large-companies-updated-rules-/F506706_en

Danish response to the Roadmap for the revision of the Non Financial Reporting Directive (NFRD) (online). [Accessed on 10.06.21]: https: / / ec.europa.eu/info/ law/better-regulation / have-your-say / initiatives / 12129-Divulgacion-de-informacion-no-financiera-por-parte-de-las-grandes-empresas-normas-actualizadas-/ F506724_es

ETUC Position for a European directive on mandatory Human Rights due diligence and responsible business conduct (draft position) (online). [Accessed on 10.06.21]: https: / / www.etuc.org/en/document/ etuc-position-european-directive-mandatory-human-rights-due-diligence-and-responsible

Impact Investing Institute's Response to the Non-financial Disclosure Regulation (NFDR) Inception Impact Assessment (online). [Accessed on 10.06.21]: https: / / www. impactinvest.org.uk/wp-content/uploads / 2020/11/ Extracts-Impact-Investing-Institute-response-to-EU-Consultation-on-revision-of-the-Non-Financial-Reporting-Directive-11.06.20.pdf

Info EUROPEANISSUERS Feedback on Non-financial reporting by large companies (online). [Accessed on 10.06.21]: https:// ec.europa.eu/info/law/better-regulation / have-your-say / initiatives / 12129-Non-financial-reporting-by-large-companies-updated-rules-/F506729_en 
r3.0 Feedback on Non-financial reporting by large companies (online). [Accessed on 10.06.21]: https://r3dot0. medium.com / r3-0-feedback-on-revision-of-the-eu-nonfinancial-reporting-directive-1cc705a77f27

Rethink Plastic Alliance's response to the roadmap consultation for the inception impact assessment of the revision of the Non-Financial Reporting Directive (online). [Accessed on 10.06.21]: https: / / ec.europa.eu/ info/law / better-regulation / have-your-say / initiatives / 12129-Divulgacion-de-informacion-no-financiera-por-parte-de-las-grandes-empresas-normas-actualizadas-/F506692_es

Ferreira, B. "The Use of Animals Inside the Fashion Industry" BA Fashion Marketing and Communication Level 6, 2016.

Fionda-Douglas, A. and Moore, C. "The anatomy of the luxury fashion brand", Journal of Brand Management, 16:5, 2009, pp.347-363, doi:10.1057/bm.2008.45.

Garcia-Torres, S., Rey-Garcia, M., and Albareda-Vivo, L. "Effective Disclosure in the Fast-Fashion Industry: from Sustainability Reporting to Action" Sustainability, 9, 2017, pp. 2256-2283, doi.org/10.3390/ su9122256.

Gelles, D. "Patagonia v. Trump", The New York Times, 2018.

German Institute for Human Rights. "Bringing Human Rights into Fashion: Issues, challenges and underused potentials in the transnational garment industry", 2018.

Harper Ho, V. E. "Comply or Explain' and the Future of Nonfinancial Reporting" Lewis E Clark Law Review, 21, 2017.

H\&M Group, Sustainability Performance Report 2019, 2020.

H\&M Group, H\&M Markets and Expansion (online): https: / / hmgroup.com/about-us / markets-and-expansion/

Höök, M. and Tang, X. "Depletion of fossil fuels and anthropogenic climate change: a review" Energy Policy, 52, 2013, pp. 797-809 (online). [Accessed on 09.06.21]: https:// doi. org/10.1016/j.enpol.2012.10.046.

Inditex, Código de Conducta de Fabricantes y Proveedores Grupo Inditex (online). [Accessed on 10.06.21]: https:// www.inditex.com/documents / 10279/241032 / C\% C3\%B3digo $+\mathrm{de}+$ Conducta $+\mathrm{de}+$ Fabricantes $+\mathrm{y}+$ Proveedores $+\mathrm{de}+\mathrm{In}-$ ditex / fdb155a3-3fd9-4ac7-98aa-096a9856dbc4

Inditex Annual Report 2019 Highlights (online). [Accessed on 10.06.21]: https:/ / static.inditex.com/annual_report_2019/en/

Jacobs, B. W. and Singhalb, V. R. "The effect of the Rana Plaza disaster on shareholder wealth of retailers: Implications for sourcing strategies and supply chain governance", Journal of Operations Management, 49-51, 2017, pp. 52-66 (online). [Accessed on 09.06.21]: https: / / doi.org/10.1016/j.jom.2017.01.002.

Jacometti, V. "Circular Economy and Waste in the Fashion Industry," Laws, 8:4, 2019. DOI: 10.3390 / laws8040027.
Jeffwitz, C. and Gregor, F. "Comparing the Implementation of the EU Non-Financial Reporting Directive", 2017, (online). [Accessed on 09.06.21]: http:/ / dx.doi.org/10.2139/ ssrn.3083368.

Karaosman, H. “Sustainability Integration in Luxury Fashion Supply Chains: An Empirical Investigation of Leather and Textiles in Italy", 2018 (online). [Accessed on 09.06.21]: http: / / oa.upm.es / 49697/1/HAKAN_KARAOSMAN. pdf.

Kering, Sustainability Principles Kering Luxury Activities (online). [Accessed on 10.06.2021]: https: / / keringcorporate. dam.kering.com / m / 0cb4a4b5740cf783 / original /Sustainability-Principles_EN.pdf

Kering, Modern Slavery Statement 2019a (online). [Accessed on10.06.2021]:https: / / r.lvmh-static.com/uploads / 2020/06/ lvmh_ra_responsabilite-environnementale_2019_en.pdf

Kering, Methodological Note - Environmental Reporting 2019b (online). [Accessed on 10.06.2021]: https: / / www.kering.com/ en/ sustainability / reporting-and-ranking/ reporting-and-indicators /

Kering, Environmental Profit \& Loss 2019 Group Results, 2019c (online). [Accessed on 10.06.2021]: https: / / keringcorporate.dam.kering.com / m / 788c4d5588730055/original / Kering-EP-L-report-2019.pdf

Kering Sustainability Progress Report 2017-2020 (online). [Accessed on 10.06.2021]: https://progress-report.kering. com/Kering-Sustainability-Progress-Report-2017-2020.pdf Khan, S. and Malik, A. "Environmental and health effects of textile industry wastewater," Environmental deterioration and human health, 2014, pp. 55-71, DOI: 10.1007/978-94-007-7890-0.

LVMH Environmental Responsibility Report 2019 (online). [Accessed on 10.06.2021]: https://r.lvmhstatic.com/uploads / 2020/06/lvmh_ra_responsabiliteenvironnementale_2019_en.pdf

LVMH 2019 Social Responsibility Report(online). [Accessed on 10.06.2021]: https://r.lvmh-static.com/ uploads / 2020/06/lvmh_rse_accessible_300720_wa_ en.pdf

Lundblad, L. and Davies, I. A. "The values and motivations behind sustainable fashion consumption", Journal of Consumer Behaviour, 15:2, 2015, pp. 149-162, (online). [Accessed on 09.06.21]: https: / / doi.org / 10.1002 / cb.1559.

Marcario, R. "Patagonia CEO: This Is Why We're Suing President Trump", Time, 2017, (online). [Accessed on 09.06.21]: https://time.com/5052617/patagonia-ceo-suingdonald-trump/

McKinsey \& Company, Survey: Consumer sentiment on sustainability in fashion, 2020.

McKinsey \& Company, The State of Fashion 2021: In search of promise in perilous times, 2020. 
Moncler Consolidated Non-Financial Statement 2019 (online). [Accessed on 10.06.2021]: https: / / www.monclergroup.com/ en/sustainability

MUD Jeans Sustainability Report 2018 (online). [Accessed on 10.06.2021]: https://www.dropbox.com/s / aw4g1ui0105c2dc/MUD-Jeans-Sustainability-Report-20183. pdf? $\mathrm{dl}=0$

New York Times, "H\&M, a Fashion Giant, Has a Problem: \$4.3 Billion in Unsold Clothes", 2018 (online). [Accessed on 09.06.21]: https://www.nytimes.com/2018/03/27/ business / hm-clothes-stock-sales.html

Patagonia Works, Annual Benefit Corporation Report, 2017.

Patagonia Works, Annual Benefit Corporation Report, 2019.

Pedersen, E. R. G. and Andersen, K. R. "Sustainability innovators and anchor draggers: a global expert study on sustainable fashion", 19:3 Journal of Fashion Marketing and Management, 2015, pp. 315-327, DOI: 10.19080/ CTFTTE.2019.04.555648.

Pencarelli, T., Ali Taha, V., Škerháková, V., Valentiny, T., and Fedroko, R. "Luxury Products and Sustainability Issues from the Perspective of Young Italian Consumers" Sustainability, 12, 2020, pp. 245-270, doi:10.3390/su12010245.

Reuters, "Forever 21 closing stores in bankruptcy filing shows limits to fast fashion", 2019, (online). [Accessed on 09.06.21]: https:/ / www.reuters.com/article/ us-forever21bankruptcy-idUSKBN1WF043

Shen, B., Minner, S., Hau-Ling, C. and Brund, A. "Logistics and supply chain management in the luxury industry", Transportation Research Part E: Logistics and Transportation Review, 143, 2020

SMART, "End-to-end analysis of Sustainability Hot Spots in the Ready-MadeGarment Industry", Smart Deliverable, 2017 (online). [Accessed on 09.06.21]: https:/ / www.smart.uio.no/ publications / reports / d3.1.-revised-hotspots-analysis-wp3.pdf

Steffen, W.; Richardson, K.; Rockström, J.; Cornell S.E.; Fetzer, I.; Bennett, E.M.; Biggs, R.; Carpenter, S.R.; de Vries, W.; de Wit, C.A.; Folke, C.; Gerten, D.; Heinke, J.; Mace G.M.; Persson, L.M.; Ramanathan, V.; Reyers, B.; Sörlin, S. "Planetary boundaries: Guiding human development on a changing planet" Science, 347:6223, 2015, DOI: 10.1126/ science. 1259855 .

Steiner, G., Geissler B., Schreder G. and Zenk, L. “Living sustainability, or merely pretending? From explicit selfreport measures to implicit cognition", Sustainability Science, 13, 2018, pp. 1001-1015, DOI: 10.1007/s11625-018-0561-6.

The Atlantic Times (2008) "The Fashion Revolution Does being ethical mean wearing the right T-shirt?", 2008 (online). [Accessed on 09.06.21]: https://web.archive.org/ web / 20110716023356/ http: / / www.atlantic-times.com/ archive_detail.php?recordID $=1383$
The Business Research Company, Apparel Global Market Report 2021: COVID-19 Impact and Recovery to 2031, 2020a.

The Business Research Company, Ethical Fashion Global Market Opportunities and Strategies to 2030: COVID-19 Growth and Change, 2020b.

The Business Research Company, Fast Fashion Global Market Report 2020-30: COVID-19 Growth and Change, 2020c.

UNCTAD, "COVID-19 has changed online shopping forever, survey shows", 2020 (online). [Accessed on 09.06.21]: https: / / unctad.org/ news / covid-19-has-changed-onlineshopping-forever-survey-shows.

UN Environment Programme, "Sustainability and Circularity in the Textile Value Chain: Global Stocktaking", 2020.

Vigneau, L. Humphreys, M. and Moon, J. "How do firms comply with international sustainability standards? Processes and consequences of adopting the global reporting initiative", Journal of Business Ethics, 131:2, 2015, pp. 469-486, DOI: 10.1007/ s10551-014-2278-5. 